\title{
Post Harvest Storage and Processing Changes in Carotenoids and Micronutrients in Fluted Pumpkin (Telferia occidentalis Hook F.)
}

\author{
${ }^{1}$ F. Okpalamma, ${ }^{2}$ P.C Ojimelukwe, ${ }^{1}$ E.A.Mazi \\ ${ }^{1}$ Department of Food Science and Technology, Abia state University Uturu PMB 2000, Abia State, Nigeria \\ ${ }^{2}$ Department of Food Science and Technology, Michael Okpara University of Agriculture Umudike, PMB 7267 \\ Umuahia, Abia state, Nigeria.(Corresponding author)
}

\begin{abstract}
The aim of this study was to investigate the effects of storage and processing on the carotenoids, vitamins and minerals of Telfairia occidentalis (Fluted Pumpkin) leaves. High Performance Liquid Chromatography (HPLC) was used to analyze the contents of the carotenoids in raw, stored and processed vegetables. The results indicated that T. occidentalis was rich in lutein $(655.70 \mu \mathrm{g} / \mathrm{gdwt})$ and total $\beta$-carotene $(230.82 \mu \mathrm{g} / \mathrm{gdwt})$. Thermal processing significantly $(p>0.05)$ increased the contents of carotenoids. Betacarotene isomerized during thermal processing. The storage conditions resulted in non-significant increase in the contents of the carotenoids. Preliminary nutritional data including the mineral elements ( $K, \mathrm{Ca}, \mathrm{Mg}, \mathrm{Zn}$ and $\mathrm{Fe}$ ) and vitamins content (Ascorbic acid, riboflavin, thiamin and niacin) indicated that T.occidentalis is a good source of iron ( $8-9 \mathrm{mg} / 100 \mathrm{~g}$ edible portion), ascorbic acid $(88-160 \mathrm{mg} / 100 \mathrm{~g}$ edible portion) and vitamin $\mathrm{K}$ $(115-125 \mathrm{mg} / 100 \mathrm{~g}$ edible portion). Cooking decreased the contents of water soluble vitamins and minerals. The concentrations of lutein, $\beta$-carotene and certain micronutrients in T. occidentalis are much higher than typical contents in conventional edible leafy vegetables. The results of this study therefore provide evidence that fluted pumpkin leaf could be important contributor in reducing hidden hunger in populations that consume adequate amounts of this vegetable.
\end{abstract}

Keywords: micronutrients, pro-vitamin A, Telferia occidentalis, processing, storage,

\section{Introduction}

Telfairia occidentalis Hook $f$. (Fluted Pumpkin) belongs to the family Cucurbitaceae. It is a tropical vine grown in West Africa as a leaf vegetable and for the edible seeds. The tender shoots, succulent leaves and immature seeds are cooked and consumed as vegetable [1]. Fresh leafy vegetables contribute vitamins, minerals and biologically active compounds[ [2]. Leafy vegetables also contain photosynthetic pigments (chlorophylls and carotenoids) [3]. These pigments produce specific colors on the food, which is one of the assessed visual quality attributes [4]. However, the functional components of the pigments play important roles in human health [5]. For example carotenes are the sources of vitamin A. Lutein and zeaxanthin are important factors for human vision [6]. Carotenoids and chlorophylls play important roles in the prevention of various diseases associated with oxidative stress, such as cancer, cardiovascular diseases and other chronic diseases. Vegetables are one of the most cost-effective and sustainable solutions to micronutrient deficiencies, which affect far more people than hunger alone, and this is crucial in most of sub-Saharan Africa [7].

The aim of this study is to evaluate carotenoids vitamins and minerals in T. occidentalis given different processing and storage treatments. Also, vegetables are often cooked before consumption in Africa. As cited in several literatures, leafy vegetables have been used in various micronutrient (especially Vitamin A) intervention programmes in several countries [8]. The results of this study will therefore determine whether fluted pumpkin leaf can potentially contribute to the alleviation of micronutrient deficiency in vulnerable populations. This will help to adequately establish its importance in human nutrition and provide basis for improved utilization of the crop.

\section{Materials and methods}

2.1 Collection of Sample::The crop Telfairia occidentalis was planted (October 2011) and harvested from two farms (in Enugu State, Nigeria) in December 2011. Natural organic manure was used as fertilizer for the crop. It was selected at random from the plant area and picked by hand mid-morning during the harmattan season. A minimum of $1 \mathrm{~kg}$ of the crop was collected randomly from different plants within the field. The leaves were placed in black polyethelene bags and transported to Biochemistry Department of the University of Nigeria Nsukka for processing and analysis. Analyses of carotenoids on the dried and milled sample were carried out at IITA (International Institute of Tropical Agriculture) Ibadan, Nigeria. 
2.2 Experimental Design: The experiment design was a randomized complete block design having vegetable type (1) and processing treatments (3) as some of the variations (giving 1 × 3 observations). Each observation was repeated three times (giving $3 \times 3=9$ observations) for each parameter tested

2.3 Processing of Ssamples: The edible and inedible portions of the samples were separated. The inedible portions were discarded. The edible portions were washed with tap water and were subsequently divided in three equal sub-samples. The first sub-sample was cooked for $5 \mathrm{mins}$ in boiling water with the lid on. The second subsample was wrapped in a newspaper and stored in the dark for 5 days at room temperature $\left(29 \pm 2^{\circ} \mathrm{C}\right)$, while the third sub-sample was analyzed raw The vitamins analyzed were ascorbic acid, riboflavin, thiamin, niacin and vitamin $\mathrm{K}$. The minerals analyzed were potassium, calcium, magnesium, zinc and iron

2.4 Carotenoid Analysis :Both the raw, cooked and stored samples were oven dried in glass trays at $50^{\circ} \mathrm{C}$ for about $48 \mathrm{~h}$ until there was no further moisture loss. The dried leaves were milled and sieved through a $1 \mathrm{~mm}$ stainless steel sieve to obtain a homogenized sample. Approximately $30 \mathrm{~g}$ of each of the sieved powdered sample was stored in a sealed polyethylene bag and coded. The samples were stored at $-20^{\circ} \mathrm{C}$ until they were analyzed for carotenoids.

2.5 HPLC Determination of Carotenoids :The method of Howe and Tanumihardjo [ (9) was used. A Waters HPLC system (Water Corporation, Milfored, MA) consisting of a Guard-column, $\mathrm{C}_{30}$ YMC carotenoid column $(4.6$ X $250 \mathrm{~mm}, 3 \mu \mathrm{l})$ water 626 binary HPLC pump, 717 auto sampler and a 2996 photodiode array detector was used for carotenoid quantification. Chromatograms were generated at $450 \mathrm{~nm}$. Identification of lutein, $\beta$ cryptoxathin, and $\beta$-Carotene were carried out using standards and with verification of absorption spectrum. Standard curves for lutein, $\beta$-cryptoxanthin and $\beta$-carotene standards already established in the crop utilization laboratory of IITA Ibadan, Nigeria were used.

2.6 Spectrophotometric Determination of Total Carotene Content: Determination of total carotene content of the leaf samples was according to the method of Rodriguez-Amaya and Kimura [10]. The absorbance was read at 450nm using Jenway Spectrophotometer (Model 752, England).

Total carotene content. $(\mu \mathrm{g} / \mathrm{g})$

$$
=\frac{A_{f r 1} \times \text { volume }(\mathrm{ml}) \times 10^{4} \times(D F)}{A_{1 \mathrm{~cm}}^{1 \%} \times \text { sample weight }} \times 1.25
$$

Where,

$A_{\text {fr1 }}=$ Absorbance at $450 \mathrm{~nm}$

Volume $(\mathrm{ml})=$ volume of fraction $1(5 \mathrm{ml})$

$A_{1 \mathrm{~cm}}^{1 \%}=2592$ (absorption coefficient of $\beta$-carotene in petroleum ether (P.E)

2.7 Determination of Vitamins: Vitamin content of Telfairia occidentalis leaf was determined by standard AOAC methods[ [11].

2.8 Determination of Minerals: Mineral content was determined after wet digestion of samples using standard AOAC methods [11]. The solution obtained after wet digestion was evaluated for its content of potassium, calcium, magnesium, zinc and iron. Atomic Absorption Spectrophotometer (AAS) (Buck Scientific 210VGP) was used for the detection of the minerals.

2.9 Statistical Analysis: Analysis of data was performed using the Statistical Package for Social Science (SPSS) version 17. Analysis of Variance was specifically performed to detect significant differences $(\mathrm{P} \leq 0.05)$ among the sample means followed by the application of Least Significant Difference test (LSD) for the separation of significant means.

\section{Results}

3.1 Chromatographic Profiles of Carotenoids: The chromatogram of the carotenoids in T. occidentalis is presented in figures 1a-c. Two classes of carotenoids (xanthophylls and carotenes) were identified and quantified. Carotenoids were eluted in the following order: Lutein, $\beta$-cryptoxanthin, 13-cis $\beta$-carotene, 15 -Cis$\beta$-carotene, trans- $\beta$-carotene and 9-cis- $\beta$-carotene/ Peaks were more pronounced in the cooked sample (B) 
A

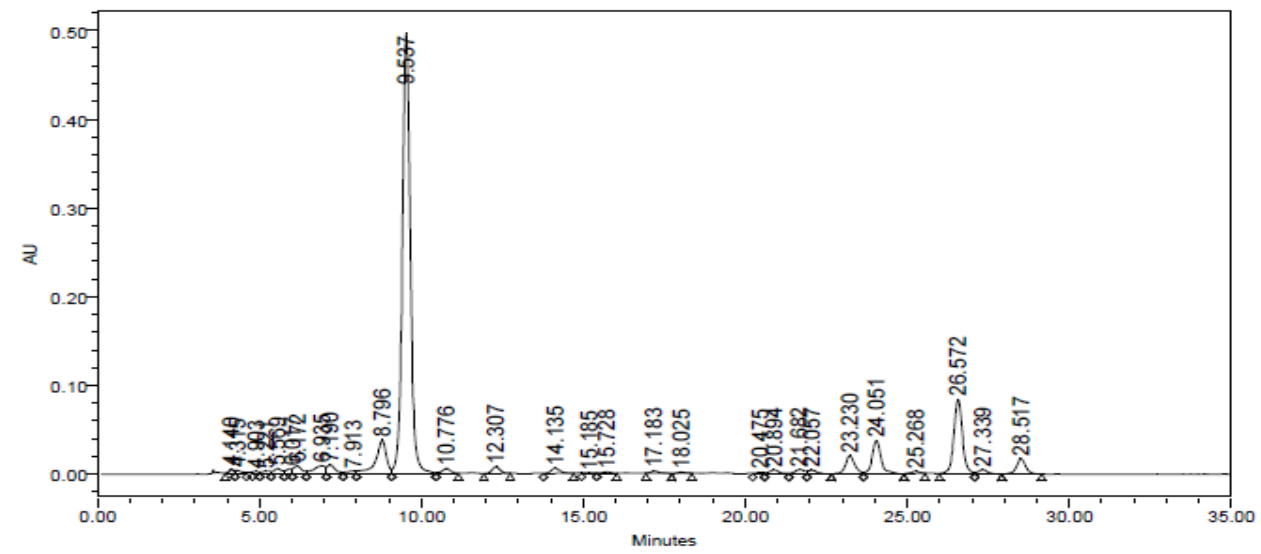

B

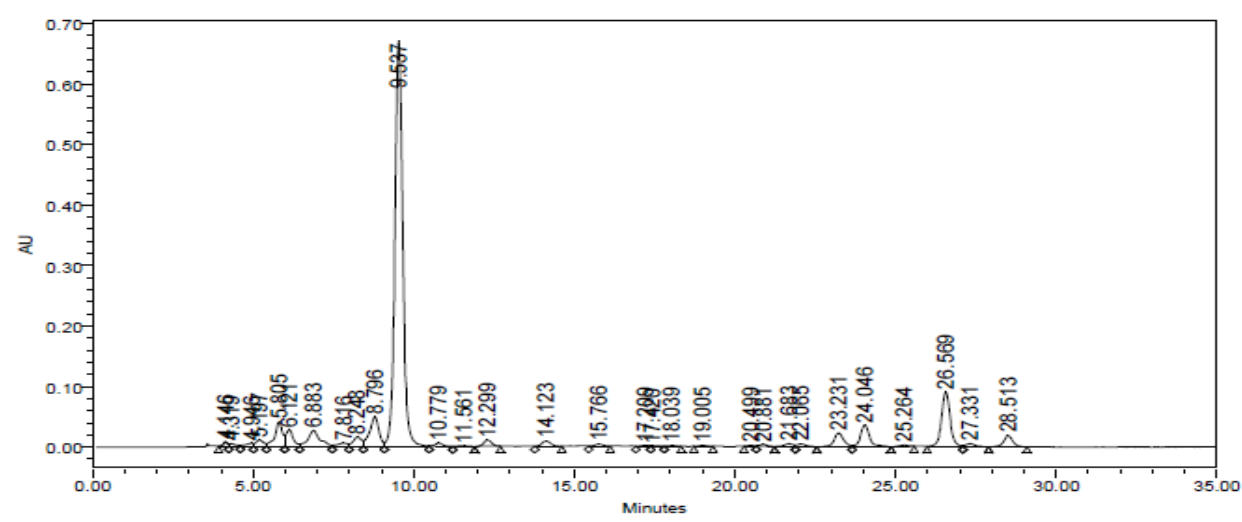

C

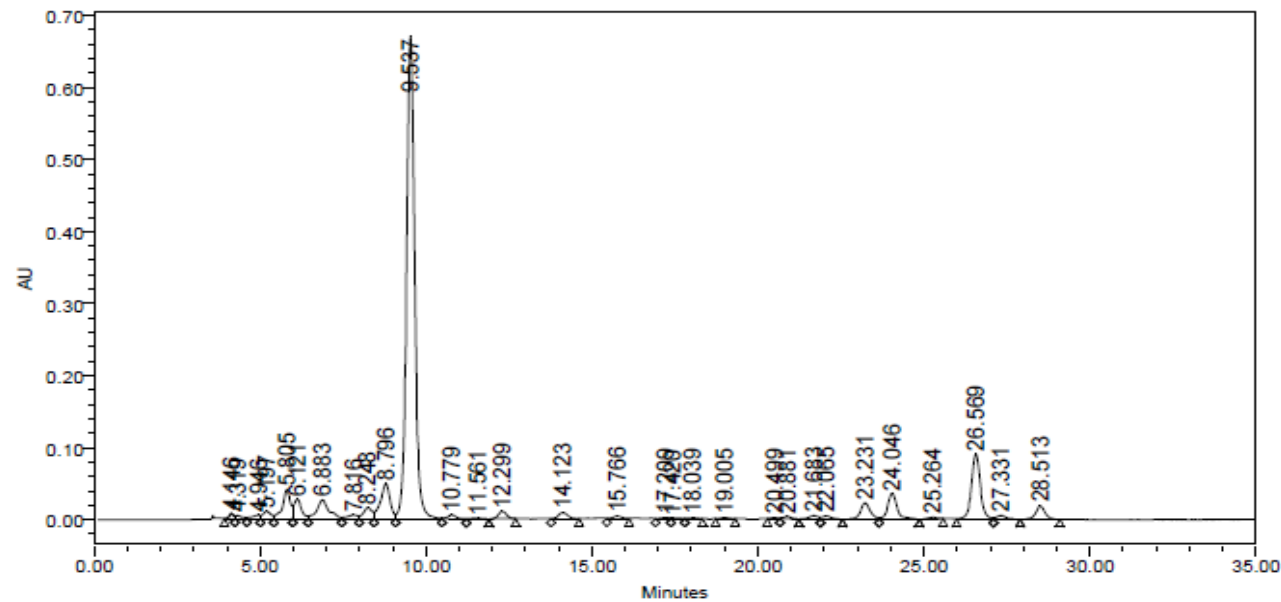

\section{(C) Stored}

Figure 1: Carotenoid Profile of Telfairia occidentalis leaf samples by HPLC (A) Raw (B) Cooked

\section{Total $\beta$-carotene content}

Table 1 shows the total $\beta$-carotene concentrations of $T$. occidentalis leaf as a result of storage and cooking treatments. The total $\beta$-carotene $(\mathrm{T} \beta$-c) level was significantly $(\mathrm{P}<0.05)$ higher in cooked leaf $(532.66 \mu \mathrm{g} / \mathrm{gdwt})$ than in raw leaf $(230.82 \mu \mathrm{g} / \mathrm{gdwt})$. Table 1 also shows a non-statistical increase in stored leaf $\mathrm{T} \beta-\mathrm{C}$ content $(245.42 \mu \mathrm{g} / \mathrm{gdwt})$ when compared with the raw leaf $(230.82 \mu \mathrm{g} / \mathrm{gdwt})$. This could result from continuation of physiological reactions [12].

Table 1 Effect of storage and processing methods on carotenoid content of Telferia occidentalis leaves

\begin{tabular}{llcl}
\hline & Treatment & & \\
\hline Carotenoids & Raw & Cooked & Stored \\
\hline Lutein & $655.70^{\mathrm{b}} \pm 4.95$ & $1158.83^{\mathrm{a}} \pm 0.06$ & $885.65^{\mathrm{b}} \pm 2.36$ \\
$\beta$-crypto & $5.17^{\mathrm{b}} \pm 0.07$ & $7.13^{\mathrm{a}} \pm 0.16$ & $4.99^{\mathrm{b}} \pm 0.14$ \\
xanthin & & & \\
9-cis- $\beta$ - carotene & $26.47^{\mathrm{b}} \pm 2.29$ & $50.78^{\mathrm{a}} \pm 1.05$ & $28.50^{\mathrm{b}} \pm 0.72$ \\
13 -cis- $\beta$ - carotene & $32.03^{\mathrm{b}} \pm 1.39$ & $90.72^{\mathrm{a}} \pm 0.10$ & $35.97^{\mathrm{b}} \pm 0.11$ \\
\hline
\end{tabular}




\begin{tabular}{|c|c|c|c|}
\hline 15 -cis- $\beta$ - carotene & $54.65^{b} \pm 0.62$ & $121.67^{\mathrm{a}} \pm 2.19$ & $53.34^{b} \pm 0.50$ \\
\hline rans- $\beta$ - carotene & $117.68^{\mathrm{b}} \pm 2.18$ & $269.48^{\mathrm{a}} \pm 0.69$ & $127.6^{\mathrm{b}} 1 \pm 2.23$ \\
\hline Total- $\beta$ - carotene & $230.82^{b} \pm 4.96$ & $532.66^{\mathrm{a}} \pm 13.94$ & $245.42^{\mathrm{b}} \pm 7.96\left(\mathrm{LSD}_{0.05}=2.03\right)$ \\
\hline
\end{tabular}

The $\beta$-crytoxanthin (a xonthophyll) content of the leaf was relatively small (Table 1 ) $\beta$-cryptoxanthin is a minor provitamin A constituent of leaves [ (13). The $\beta$-cryptoxanthin content of the cooked leaves $(7.13 \mu \mathrm{g} / \mathrm{gdwt})$ was significantly $(\mathrm{P}>0.05)$ higher than in both the raw $(5.17 \mu \mathrm{g} / \mathrm{gdwt})$ and stored $(4.99 \mu \mathrm{g} / \mathrm{gdwt})$ leaf samples.

Lutein content of the cooked leaf $(1158.83 \mu \mathrm{g} / \mathrm{gdwt})$ was significantly $(\mathrm{p}<0.05)$ higher than in both the raw $(655.70 \mu \mathrm{g} / \mathrm{gdwt})$ and stored $(885.65 \mu \mathrm{g} / \mathrm{gdwt})$ leaf samples (Table 1$)$.

3.2 Provitamin A Content: The Provitamin A content of the leaf sample was calculated (Table 2). The provitamin A content of the raw, cooked and stored leaf sample were 233.41, 536.22 and 247. $91 \mu \mathrm{g}$ respectively.

Table 2 Pro-vitamin A values of cooked and stored Telferia occidentalis

\begin{tabular}{ccc}
\hline $\begin{array}{c}\text { Provitamin A } \\
(\mu \mathrm{g} / \mathrm{g})\end{array}$ & $\begin{array}{c}\text { \% trans } \\
\text { of total } \beta \text {-Carotene }\end{array}$ & (Total $\beta$-Carotene) \\
\hline 233.41 & 51.0 & - \\
536.2 & 50.6 & 230.76 (after cooking) \\
247.91 & 52.0 & 106.32 (after storage) \\
\hline
\end{tabular}

Values are means \pm standard deviations of duplicate determinations on dry weight basis. Means with different superscripts within the same column are significantly different $(P \leq 0.05)$

3.3 Mineral Content: The effects of storage and processing on selected minerals of $T$. occidentalis is presented in Table 3. The mineral contents of the raw leaves were $\mathrm{K} .3 .45$; Ca. 1.50; $\mathrm{Mg}, 4.30 ; \mathrm{Zn}, 2.00$ and $\mathrm{Fe} 8.90$ (mg/100g respectively).

Table 3: Effects of storage and processing methods on selected mineral content of Telfairia occidentalis

Mineral content (mg/100g edible portion fresh weight basis)

\begin{tabular}{lllllll}
\hline Treatment $\mathbf{~ K}$ & $\mathbf{C a}$ & $\mathbf{M g}$ & $\mathbf{Z n}$ & $\mathbf{F e}$ \\
\hline Raw & $3.45^{\mathrm{b}} \pm 0.07$ & $1.50^{\mathrm{b}} \pm 0.14$ & $4.30^{\mathrm{b}} \pm 0.14$ & $2.00^{\mathrm{b}} \pm 0.28$ & $8.90^{\mathrm{b}} \pm 0.14$ & \\
Cooked & $3.20^{\mathrm{a}} \pm 0.00$ & $1.00^{\mathrm{a}} \pm 0.14$ & $4.05^{\mathrm{a}} \pm 0.21$ & $1.70^{\mathrm{a}} \pm 0.14$ & $8.05^{\mathrm{a}} \pm 0.35$ \\
Stored & $3.35^{\mathrm{b}} \pm 0.07$ & $1.47^{\mathrm{b}} \pm 0.07$ & $4.23^{\mathrm{b}} \pm 0.07$ & $2.0^{\mathrm{b}} \pm 0.07$ & $8.74^{\mathrm{b}} \pm 0.35$ & $\mathbf{L S D}=\mathbf{3 . 8 1}$ \\
\hline
\end{tabular}

Values are mean \pm standard deviation of triplicate determination on fresh weight basis means with different superscripts within the same column are significantly different $(p=0.05)$.

3.4 Vitamin Content: The vitamin content of T. occidentalis leaves is shown in Table 4. Vitamin concentrations (in $\mathrm{mg} / 100 \mathrm{~g}$ ) were $160.15,2.07,0.08$ and 2.38 for ascorbic acid, riboflavin, thiamin and niacin respectively, while vitamin $\mathrm{K}_{1}$ content was $210 \mu \mathrm{g} / 100 \mathrm{~g}$. Cooking significantly $(\mathrm{P}<0.05)$ decreased the contents of the watersoluble vitamin [13]. However, cooking increased significantly $(\mathrm{P}<0.05)$ the content of vitamin $\mathrm{K}_{1}$ in the leaf. Table 4: Effects of storage and processing methods on the content of selected vitamin of Telfairia

occidentalis leafy vegetable

Vitamin content per $100 \mathrm{~g}$ edible portion, fresh weight basis

\begin{tabular}{|c|c|c|c|c|c|}
\hline Treatmen & Ascorbic & Riboflavin & Thiamin & Niacin & Vit. K \\
\hline & Acid (mg) & (IIIg) & IIg) & (mg) & $(\mu \mathrm{g})$ \\
\hline Raw & $160.15^{b} \pm 0.07$ & $2.07^{b} \pm 0.01$ & $0.08^{b} \pm 0.01$ & $2.38^{\mathrm{b}} \pm 0.01$ & $121^{b} .05$ \\
\hline Cooked & $88.10^{a} \pm 0.07$ & $1.02^{\mathrm{a}} \pm 0.01$ & $0.04^{\mathrm{a}} \pm 0.01$ & $0.50^{\mathrm{a}} \pm 0.00$ & $125^{\mathrm{a}} .67$ \\
\hline Stored & $99.27^{\mathrm{a}} \pm 0.01$ & $1.39^{\mathrm{a}} \pm 0.07$ & $0.04^{\mathrm{a}} \pm 0.01$ & $1.49^{\mathrm{b}} \pm 0.00$ & $115^{\mathrm{a} .98}$ \\
\hline
\end{tabular}

LSD $_{0.05}=4.05$

Values are means \pm standard deviations of duplicate determinations on fresh weight basis. Means with different superscripts within the same column are significantly different $(P \leq 0.05)$

\section{Discussion}


The results of carotenoid analysis obtained from this study correlates with the results observed by Faber et al. (14[). Processed samples had higher T $\beta$-c levels (Rodriguez-Amaya [15]. Cooking also resulted in $230.76 \%$ apparent T $\beta$-c retention when compared with the raw leaf. (Table1). Dietz and Erdman [16] reported that cooking resulted in greater than $100 \%$ retention of $\beta$-carotene in vegetables, because denaturation of carotene binding proteins releases the carotenoids so that they can be extracted more easily.

The percentage trans- $\beta$-carotene (Table 1) was lower in the cooked than in raw leaves. During cooking, some of the trans- $\beta$-carotene could have been converted to cis-isomers or other oxidation products [17]. The consequences of trans-cis-isomerization are changes in bioavailability and physiological activity $[18,19]$. The observed increase in $\mathrm{T} \beta$-c during storage resulted in an apparent retention of $106.32 \%$ (Table 1 ) indicating that the storage conditions in our study did not degrade the carotenoids. Comparing the $T \beta-c$ content of T. occidentalis, with previous reports, ŽnidarČiČ et al. [20] recorded $70.1 \mu \mathrm{g} / \mathrm{gfwt}$ and $79.6 \mu \mathrm{g} / \mathrm{gfwt}$ in wild rocket and Garden rocket respectively. It seems therefore, that the Fluted pumpkin leaf is a very rich dietary source of $\beta$-carotene.

The most abundant $c i s$-isomer of $\beta$-carotene in the raw, stored and cooked samples was 13-cis- $\beta$ carotene (Table 1). Out of the several different geometric isomers of $\beta$-carotene that exist in food and human tissues, the major $\beta$-carotene isomers in the circulation of humans are trans- $\beta$-carotene, with small amount of 13-cis- and 9-cis- $\beta$-carotene (21). Several researchers have observed high lutein content in green leafy vegetables [13, 22]. According to Wisniewka and Subczynski [6], the presence of lutein and/or zeaxanthin in the diet may be beneficial for reducing the incidence of the two common eye diseases of ageing, age related macular degeneration and cataracts formation. From our results, consumption of $50-70 \mathrm{~g} /$ day of the cooked leaves analyzed in our study would meet the recommended daily allowance (RDA) of 900RE/day for men and 700RE/day for women, 19 - 30 years old (Souzan and ABD EL-AAl[ [23]. Higher values for calcium and potassium were reported by Agte et al. [13] in watercress Kale and cabbage and by Uusiku et al. [22] in Amaranthus spp and Solanum nigrum leaves respectively Cooking for $5 \mathrm{~min}$ at $100^{\circ} \mathrm{C}$ significantly $(\mathrm{P}<0.05)$ reduced mineral content. These minerals leach into cooking water. The reductions could also result from effects of oxidizing agents, exposure to heat, light, and extremes of $\mathrm{pH}$ and other factors that affect organic nutrients [23]. The potassium, calcium and iron values in T. occidentalis correlated well with the findings of Sobowale et al. [24] Post-harvest storage conditions resulted in non-significant reductions in the mineral contents when compared with the raw leaves.

The results for mineral analysis of fluted pumpkin suggest the consumption of large quantities to meet the recommended daily allowance (RDAs) for minerals. However, Iron content can be considered adequate when compared with an RDA of 8mg Fe/day for men (19 - 30 years) and 18mg Fe/day for women $(19-30$ years) [25]. Vitamin $K_{1}$ is located in chloroplasts in plants, cooking by boiling may disrupt the cell wall, thereby releasing vitamin $K_{1}$ for measurements [13]. The loss of ascorbic acid observed in this study was $44 \%$. The reported cases of ascorbic acid loss during blanching or cooking are enormous and may vary between 40 and $70 \%$ in some cooked vegetables when processed at $100^{\circ} \mathrm{C}$ for $10 \mathrm{~min}$. [

] Also at the end of the storage period, the loss in ascorbic acid was $38 \%$. Other researchers have also reported postharvest losses in ascorbic acid. 29-50\% and 34-38\% (24) for Cassia tora and Corchorus tridens leaves stored at $20^{\circ} \mathrm{C}$ for 8 days. Ascorbic acid, riboflavin and vitamin $\mathrm{K}$ in $T$. occidentails are high and adequate to meet the RDAs of $90 \mathrm{mg} /$ day ascorbic acid, $1.3 \mathrm{mg} / \mathrm{day}$, riboflavin and $90 \mu \mathrm{g} / \mathrm{day}$ vitamin $\mathrm{K}_{1}$ in children and adults respectively.

\section{Conclusion}

The potentials of $T$. occidentalis in alleviating micronutrient deficiencies were evaluated in this research work. Results showed that the consumption of about 50g per pay of cooked fluted pumpkin leaf would meet the required daily allowance (RDA) for Vitamin A in children and adults. Consumption of about $100 \mathrm{~g}$ of pumpkin leaf per day would meet the RDAs of riboflavin, ascorbic acid and vitamin $\mathrm{K}$ in children and adults respectively. Storage and cooking of the leaves after harvest resulted in changes in carotenoids, vitamins and minerals in the leaves. The levels of nutrient retention after domestic processing support the inclusion of this leaf in a daily diet to overcome vitamin A deficiency, iron deficiency anaemia and age-related macular degeneration.

\section{References}

[1]. M.O. Akorada. Ethno botany of Telfairia occidentalis Cucurbitaceae) among Igbo's of Nigeria. Economic Botany 44(1):1990,2939.

[2]. W. Kmiecik, Z. Lisiewskam and C. Jaworska. Effect of Storage Conditions on the Technological value of dill (Anethium graveolens L). Folia Horticulturea, 13, 2001, 33-43

[3]. M. Kimura and D.B. Rodriguez-Amaya. Carotenoid composition of hydroponic leafy vegetables. Journal of Agriculture and Food Chemistry. 51, 2003,.2603-2607 
[4]. L. Xue, and L. Yang. Deriving leaf chlorophyll content of green leafy vegetables from hyperspectral reflectance. ISPRS Journal of Photogrammetry and Remote Sensing, 64, 2009, $97-106$

[5]. Y.T. Liu, C.O. Perera, and V.Suresh. 2007. Comparison of three chosen vegetables with others from South East Asia for their Lutein and zeaxanthin content. Food Chemistry, 101, 2007, 1533-1539

[6]. A. Wisniewska, and W.K. Subczynski.. Accumulation of macular xanthophylls in unsaturated membrane domains. Free Radical Biology \& medicine. 40, 2006, $1820-1826$

[7]. IPGRI. International Plant Genetic Resources Institute. Conserving and increasing the use of Neglected and underutilized crop species (2001-2005). Retrieved October 15, 2005 from http://www.ipgri.cigar.org/institue/siteinfo.html

[8]. Northrop-Clewes, C. 2003. Report of the $21^{\text {st }}$ International vitamin A consultative Group Meeting, Marralech, Morocco Sight \& Life Newsletter, 3 - 5 February 1,2003, $10-34$

[9]. J.A. Howe and S.A. Tanumihardjo. Evaluation of analytical methods for carotenoid extraction from biofortified maize (Zea mays sp) Journal of. Agriculture and. Food Chemistry. 54, 2006, $7992-7994$

[10] D.B. Rodriguez-Amaya and M. Kimura. Harvest plus handbook for carotenoid analysis. Harvest-plus: Washington, D. C., and Cali, Columbia, 2004

[11]. A.O.A.C.. Official Methods of Analysis. Association of official Analytical Chemists. $18^{\text {th }}$ edition. Washington, D.C, 2005 Pp 242 268

[12]. L.A. Howards, A.D. Wong, A.K. Perry, and B.P. Klein. $\beta$-carotene and ascorbic acid retention in fresh and processed vegetables Journal of. Food Science. 64, 1999, $929-936$

[13]. W. Agte, K.V. Tarwadi, S. Mengale, and D. Chiplonkar. Potential of traditional cooked green leafy vegetable as natural sources for supplementation of eight Micronutrients in vegetarian diets. Journal of. Food Composition and Analysis. 13:2000. 885 - 891

[14]. M. Faber,A. Olelofse, P.J Van Jaarsveld, F.A.M. Wenhold and Jansen W.S. Van Rensburg, W. S. African leafy vegetables consumed by households in the Limpopo and Kwaszulu-Natal Provinces in South Africa. South African Journal of Clinical Nutrition 2(1), 2010, 30-38

[15]. D.B. Rodriguez-Amaya. Effects of processing and storage on food carotenoids. Sight and Life Newsletter. 3(Special Issue), 2002 $25-35$.

[16]. J.M. Dietz, and J.W. Erdman. Effects of thermal processing upon vitamins and proteins in foods. Nutrition Today. July/August 1989, 6-15.

[17]. H. Nyambaka and J. Ryley. An Isocratic reversed-phase HPLC separation of the stereoisomers of the provitamin A carotenoids $(\alpha$ and $\beta$-carotene) in dark-green vegetables Food Chemistry 55 (1), 1966, 63 - 72.

[18]. J.M. Casternmiller and C.E. West. Bioavailability and bioconversion of carotenoids. Annual Review of Nutrition 18; $1998,19-38$

[19]. R.M. Faulks, and S. Southian. Challenges to understanding and measuring carotenoids bioavailability. Biochemica et Biophysica Acta, 174(2) 2005, $95-100$

[]20]. D. ŽnidarČiČC, B., Dean and S. Helena. Carotenoid and chlorophyll composition of commonly consumed leafy vegetables in Mediterranean countries. Food Chemistry 129, 2011, $1164-1168$

[21]. M.Damon, Z Nancy,D.B Zhang,S, Haytowitz and C. Booth. Phylloquinone (Vitamin $\mathrm{K}_{1}$ ) content of vegetables. Journal of. Food Composition and Analysis. 18, 2005, $751-788$

[22]. N.P. Uusiku, A. Oelofse,K.G. Duodu, M.J, Bester and M.Faber. Nutritional value of leafy vegetables of sub-Saharan Africa and their potential contribution to human health. A review. Journal of Food Composition and Analysis 23, 2010, 499-509

[23]. S.L.Souzan, S.L. and ABD EL-AAl. Mineral profile - Shelf Life extension and Nutritive value of Fresh Green Leafy Vegetables consumed in Egypt. African Crop Science Conference Proceedings. 8:2007, 1817 - 1826

[24]- S.S. Sobowale,O.P. Olatidoye, O.O. Olorodo, O.K. and Sokeye. Effect of preservation methods and storage on nutritional quality and sensory properties of leafy vegetables consumed in Nigeria. Journal of Medical and Applied Biosciences 2, 2010 46-56

[25]. FBN. Food and Nutrition Board, Institute of Medicine (I.O.M). Dietary Reference intakes for vitamin A, Vitamin K., Arsenic, Boron, Chromium Copper, Iodine, Iron Manganese, Molybdenum, Nickel, Silicon, Vanadium and Zinc. National Academy Press., Washington D. C, 2005. 